\title{
BUILDING OF THE LODZ BRAND BASED ON CULTURAL RESOURCES - RESULTS OF QUALITATIVE RESEARCH
}

\author{
Wioletta Krawiec* http://orcid.org/0000-0001-5619-9467
}

\begin{abstract}
Background. The city's brand has a particularly complex and multidimensional structure. Its identity is a key component, and it is the basis for building the city's image. Increasingly, resources from cultural and creative industries form the foundation of this image. It should be mentioned that an important role in the process of building the city's image is assigned to a creative person with the ability to recognise opportunities and threats in the future and to flexibly adapt to changes in the environment.

Research aims. The article presents the potential found in cultural resources of the city of Lodz in the process of building the city's brand. It also shows the extent in which they are used or omitted, perhaps by the insufficient professional experience of cultural managers. The article also describes the profile of the manager of cultural institutions.

Methodology. Interviews with managers and employees of cultural institutions in Lodz constitute an empirical basis of the research. The data analysis was carried out following the principles of the grounded theory methodology.

Key findings. Lodz has a sufficient spectrum of cultural resources which have an impact on building the city's brand. The main ones are those that are included in the urban space and those that are created by cultural institutions in the proposed "cultural offer". Lodz should not lose its flagship events, as they contribute the most to attracting people into the city and its brand. Lodz represents a post-industrial character, new openness, and creativity in action. It also has neglected areas, such as the weakened film industry, the neglected history of the textile industry, underfunded cultural institutions, or limited relations with local governments. The managers in question perceive the city's resources as a potential, although this does not mean that they can use them effectively in the city's brand building process. Their professional development probably allows them to see opportunities and threats of the environment and helps in making decisions. However, this subject needs more in-depth research.
\end{abstract}

Keywords: city brand, cultural resources, grounded theory, cultural institutions JEL Codes: M14, M31

\footnotetext{
${ }^{*}$ Faculty of Management, Department of Marketing, University of Lodz. E-mail: wioletta. krawiec@uni.lodz.pl.
} 


\section{INTRODUCTION}

The process of building a city's brand is influenced by the resources (tangible and intangible) that the city has at its disposal, but also by people who can make use of these resources. These resources allow the brand to articulate its values, which are expressed in the city's image.

In this paper, the thematic range presented refers to Lodz's cultural resources as one of the city's significant sub-products adopted and included in the document titled The Brand Management Strategy for the years 2010-2016 (pp. 17-30). The document has specified the direction for building the city's brand based on culture, new media, and creative industry. To understand the essence and potential of the creative approach to the city's brand, the document describing activities related to the development of culture, entitled Culture Development Policy 2020+ for the City of Lodz, was prepared.

Based on qualitative research and its analysis, following the principles of grounded theory methodology, the authoress attempted to answer the question: which cultural resources of Lodz show the potential in the process of building the city's brand as the aim of the article. However, yet another question was posed: do people responsible for creating culture in the town see the potential of cultural resources in the area of development of the city's brand and whether this perception of the potential of cultural resources is a matter of the ability to see the benefits based on experience or professional maturity of the managers?

Keeping in mind the above questions, the authoress attempted to examine the literature on the subject, as well as analyse the data obtained during empirical research conducted among promotion managers in Lodz's cultural institutions. This research has been conducted successively since December 2017 within the Department of Marketing and the Department of City and Region Management of the Faculty of Management at the University of Lodz. The results presented in the article constitute only a part of the process of analysing the collected material, therefore cannot be treated as final answers to the developed research questions. 


\section{BACKGROUND}

\section{Building the city's brand and a culture manager}

The city's brand should be regarded as a particularly complex and multidimensional construct, as it results from the complexity of the territorial product. The city, similarly to the company, offers its current and potential users certain products, both tangible and intangible, in the broadly understood spatial structure of the city, which become the subject of the market exchange (Markowski, 2002). The city's brand, therefore, connects both material elements that constitute the city's reality (infrastructure, architecture, and tourism development) and intangible aspects (values and beliefs) (Korczyńska, 2006; Baker, 2012 , p. 28). The process of building the city's brand is significantly different from the process of creating a consumer product's brand. These differences come down mainly to the objectives, the level of diversification of consumer groups, and the complexity of the process (Seweryn, 2013; Kotler \& Lee, 2008). The key component of the city's brand is its identity.

Brand identity is the sum of the attributes of a place, through the prism of which it wants to be perceived by its surroundings. The place's identity is built up by a large number of many various elements which allow it to be identified and distinguished from others, creating its personality and character (Łuczak, 2000; Szromnik, 2007, pp. 136-137). The elements of the city's identity are, among others, the city's history, monuments, dominant economic activity, demography, scientific institutions, events, celebrities, inhabitants and their behaviour, etc. The city's identity is composed of fixed elements (the location, tradition, history, etc.) and variable elements (economic situation, activities of other centres) (Szwajca, 2009, p. 22). The elements of the city's identity form the basis for building its image, i.e. a mental image of the city as perceived by its recipients (e.g. the city: historical, industrial, tourist, creative, innovative, young, of cultural people (artists), etc.) (Szromnik, 2007, p. 134; Fakeye \& Crompton, 1991, pp. 10-16; Seaton \& Bennett, 1996, p. 540; Kangas, 1998, pp. 1-81). However, few cities connect the city's image with the cultural sector, which is developed in this article.

In the process of creating a city's brand based on cultural resources, the managers of cultural institutions (CI) can play a significant role. 
They become, to some extent, the guardians of the city's good image. This also requires cultural institutions to employ managers with an appropriate profile. It is not a simple task for any organisation. The reason for this is that the ideal manager's profile is constantly changing, improving, and modifying. There are many approaches in literature to describe managerial features, skills, and competencies (Tomaszuk, 2013, p. 72; Ciekanowski, 2015, pp. 185-195; Ciesielska, 2007). It is worth mentioning here the profile of the manager of the so-called "new era", whose work should be based on the $3 \times \mathrm{C}$ model: communication, creativity, and cohabitation (Wierżyński, 2010). This approach is associated with a demanding market today, in which creative managers are required (Williams, 2009, p. 29; Simerson \& Venn, 2010, p. 16). More attention is given to the soft skills of managers, which influence the success of a modern organisation. These soft skills, such as communication, interpersonal and social skills or emotional intelligence, are much more difficult to learn than, e.g. programming (Bellon, 2019).

Therefore, the culture manager will be expected to have the characteristics for creating their professional profile and intellectual potential. These should facilitate leading and managing a team of people, as well as achieving the typical goals of cultural institutions. The desired characteristics of cultural managers are described in the literature on the subject. The following can be mentioned here: sensitivity, honesty and credibility, perseverance, involvement and loyalty, ability to achieve the desired goal, high level of knowledge, and belief in success. Types of behaviour such as a positive attitude towards life and the environment, adaptability, ability to communicate, ability to build relationships, self-confidence, and self-control are also associated with these characteristics. These behaviours require personal, interpersonal, and strategic skills.

The main tasks of a contemporary cultural manager include the preparation of cultural projects (artistic undertakings and events); the obtaining of financial resources and patronage (sponsors); promotion and information on cultural ventures; contact with the media and external clients; cooperation with local, regional, and international partners; coordination and supervision of the work of a team; the conduct of cultural education; animation of cultural life of local communities (Informacja..., 2010, p. 4). 
Additionally, the cultural institution (CI) manager is also required to be involved in activities to build a brand/image of the city. It is reflected in the fact that the brand value of the city is included in the events or offer of cultural institutions. It also requires managers to identify themselves with the city. However, the thought arises here: to what extent are the CI managers involved in activities for the town?

\section{RESEARCH METHOD}

The results of the research presented in the article are the part of a larger research project entitled Cooperation between public administration and cultural institutions in the context of building a city's brand. The project has been carried out since December 2017 at the Faculty of Management at the University of Lodz within the two departments mentioned in the introduction to this article.

The scope of the analysed research results is dictated by the purpose of the article, the state of the available data and the adopted method of their analysis and deduction. The information for review in this article comes from 15 purposely selected interviews with managers and promotion specialists employed in city cultural institutions subordinate to the City of Lodz ( 15 out of 50 interviews conducted), which agreed to participate in the survey. From the answers of the respondents, it can be concluded that all the people participating in the study have higher education and are aged between 30 and 50. They have gained their professional experience in the business, public, and non-governmental sectors. The respondents work in cultural institutions such as theatres, museums, cultural centres, libraries, sports facilities.

The interviews were transcribed and then, following the accepted aim of the article and the principles of grounded theory methodology, the so-called theoretical sampling and coding were undertaken (the main elements of the grounded theory are theoretical sampling, coding, theoretical saturation, and continuous comparison, Konecki, 2000, p. 26). This process consists of searching for meanings hidden in data, comparing them, and developing and creating more general categories for individual phenomena that form the basis of theory and are constructed from lower-order elements. However, selective coding is also worth mentioning, which consists in limiting coding, 
and concentrating on one phenomenon, which is considered to be a central category and a starting point (direction) for building the theory, further analysis and determining the code hierarchy in grouping data, comparing statements and searching for correlations (Niedbalski, 2014; Gibbs, 2011). This analysis also allowed to determine the

\section{purpose of this article.}

It should also be mentioned here that the ground theory assumes researching without formulating any research hypotheses; at most, there may be the so-called initial assumptions, which, based on research, may evolve or create new ones. It is also possible not to have them at all. The ground theory gives the researcher the possibility to discover new phenomena, concepts, theories, classifications or, as a result, to find relations between categories, which may be the starting point for the formulation of research hypotheses. Hypotheses, concepts, and properties of ideas are built during empirical research; during that time, they are also modified and verified (Konecki, 2000, p. 26).

The categories and codes presented in the article are the result of analyses carried out using the adopted research procedure on the methodology of grounded theory. The respondents were not given any definitions or assumptions during the research. They could comment according to their knowledge and beliefs. Throughout the research, the questions asked were broadened or shortened; the reason for this was the research direction and the adopted research strategy, which was not limited to the respondents. It should be mentioned that in qualitative research the basis of the analysis is induction, i.e. creating generalisations based on detailed information obtained from the collected data. These studies are only cognitive in nature in order to understand or explore a new trend (Niedbalski, 2014).

The results presented in the article are subject to certain limitations. In the article, not all the codes adopted in the study were written down due to their large number. In the whole research project, 50 representatives of cultural institutions in Lodz, subordinate to the City of Lodz Office, as well as to the Marshal of the Lodz Province, joined the research. The article narrows down the discussion to 15 statements by representatives of municipal cultural institutions subordinate to the Municipal Office. Therefore, this study cannot be treated as representative. The article omits descriptions of existing assumptions between separate categories, which provide a basis for considering a more significant number of problematic threads or development of other 
hypotheses. The results of the analysis are presented in tables due to the publication limitations of the article. Organising the observed phenomena this way was to make the areas describing the resources owned by the city of Lodz and the CI manager's profile more readable.

\section{ANALYSIS OF THE RESEARCH RESULTS}

The presented results are derived from purposely selected data fragments collected in the process of the survey. Their choice was determined by pre-developed research problems, which are recorded as the aim of the article. First of all, the authoress tried to find out which cultural resources constitute the potential in the process of building the city of Lodz's brand and whether any of these resources are dominant or unused. Then the article's authoress searched for connections between whether the managers of cultural institutions also perceive the potential of cultural resources in the development of the city's brand and if the ability to see the potential of cultural resources is derived from the managers' professional experience.

Based on the category trees presented (Tables 1 and 2), the article's authoress attempted to find answers to the questions posed in the article. It should be noted that the presented codes, categories, and relations are proposals of variants from many other possible ones, which the developed material gives.

\section{Cultural resources in the process of brand building of the city of Lodz}

Table 1 presents the category tree developed in the course of data analysis using the grounded theory method. The authoress limited her considerations to selected research results, concentrating his studies on the respondents' comments on the potential of building the city of Lodz's brand based on cultural resources (mainly city identity).

According to the respondents, the position of the city on the cultural market "is defined by the cultural offer that the city presents, which can go beyond the city walls or regional awareness" (TM_IK15a). In the respondents' opinion "the position of the city on the cultural market (...) can be (placed) in the top five in Poland" (M_IK27a; respondents 


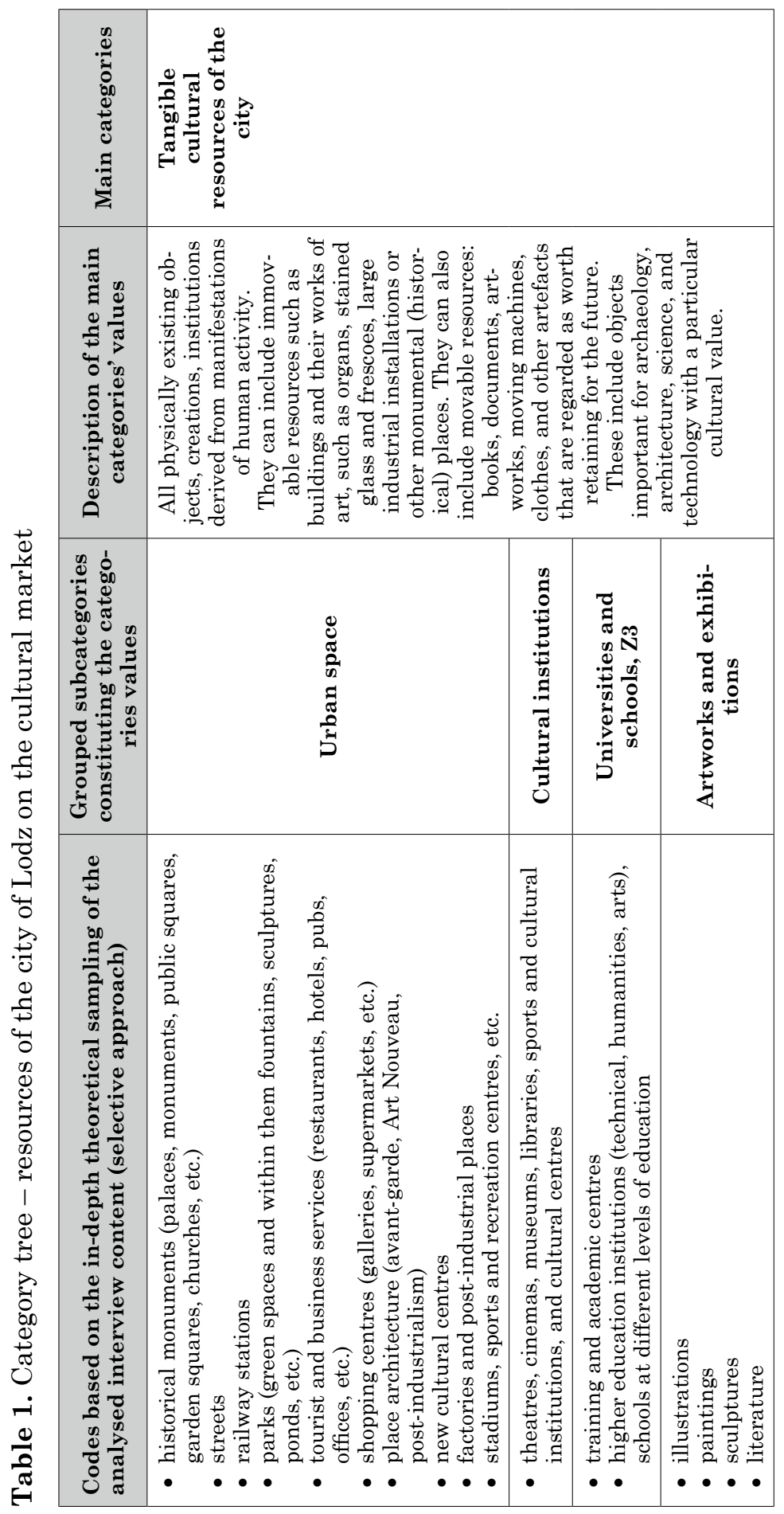




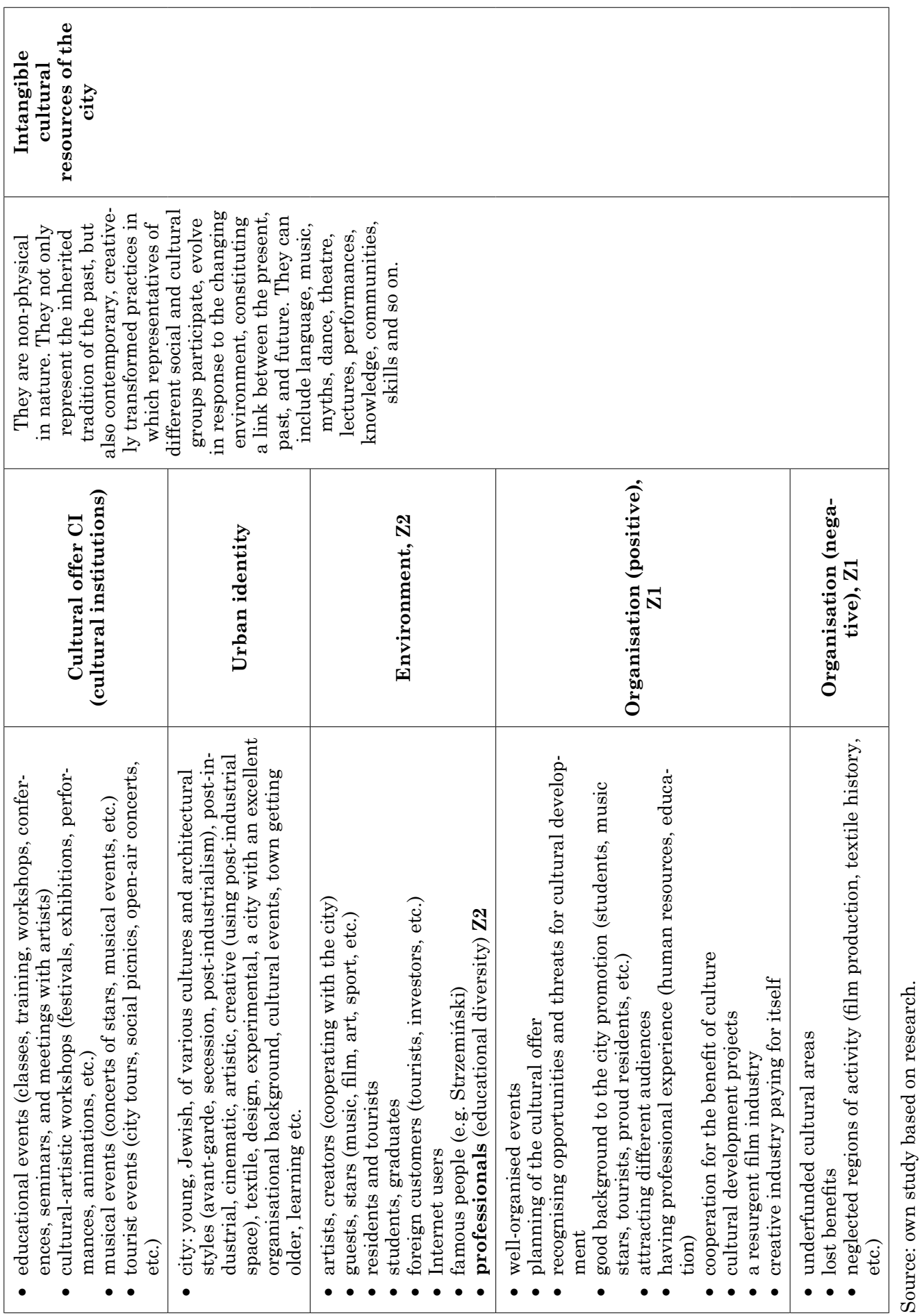


believe that Warsaw and Cracow have a better position than Lodz in the cultural resources area).

The cultural offer of the city is created by various cultural resources of a tangible and intangible nature occurring in the city space (main categories, Table 1). However, in the city branding process, intangible resources will be of great importance, as the brand itself is an intangible resource. On the other hand, tangible cultural resources allow for the consolidation of the brand identity. The analysis of the gathered research material, grouped in the "intangible cultural resources" category, allowed to distinguish the following subcategories: cultural offer, city identity, environment, and organisation (positive and negative). In the category of "tangible cultural resources" such subcategories as urban space, cultural institutions, universities and schools, works of art, and exhibitions were distinguished. The detailed description of the categories and their values (codes) can be found in Table 1.

The symbols in Table 1, Z1-3 are selected relations that have been observed between codes or categories according to the established aim of this article. It should be noted here that based on the developed categories (Tables 1 and 2), it is possible to derive much more dependencies that can be surveyed further. Due to publication limitations, the authoress is not able to show all the possibilities that can arise during the analysis.

Among the statements in the area of "tangible cultural resources", the dominant influence on the branding of Lodz turned out to be the "urban space" subcategory ("a cool public space and the city cares about it very much", TM_IK15a). The respondents were enthusiastic about the topics of the Factory Railway Station or the New Centre of Lodz with the Kobro Market Square, which in the future will connect the station with EC1; the main street of the city of Lodz - Piotrkowska Street, which has always been vibrant with life; sports and tourist facilities (the Atlas Arena); post-industrial spaces, which are developed mainly for museum, trade and tourism-business activities (Pastor's Mill, Art Factory, Museum of Textiles, Manufaktura complex, or Off-Piotrkowska); architecture of buildings (avant-garde, secession, industrialism); historic buildings which amaze with their architecture, but also with 
Table 1a. Urban space - the tangible cultural resource

\begin{tabular}{|c|c|}
\hline Codes & Citation with a respondent subscript \\
\hline $\begin{array}{l}\text { - railroad station } \\
\text { - new cultural centres }\end{array}$ & $\begin{array}{l}\text { “...maybe (...) visiting the Railway Station 'Factory', which is } \\
\text { unique on the European scale (...)" (M_IK27a). } \\
\text { "But now we have the railway station behind the fence, which } \\
\text { was built. We have other elements of this puzzle of the New } \\
\text { Centre of Lodz; there is a beautifully organised public space } \\
\text { nearby" (TM_IK15a). }\end{array}$ \\
\hline $\begin{array}{l}\text { - } \text { tourist services } \\
\text { facilities } \\
\text { - streets } \\
\text { - new cultural centres } \\
\text { - railway station }\end{array}$ & $\begin{array}{l}\text { “...besides, I remember (...) trips organised on arrival from } \\
\text { Lodz pubs (...) because } 100 \text { pubs were in Piotrkowska Street, } \\
\text { and naturally there was something to do (...) there were still } \\
\text { spaces that were created, for example, EC1 in New Lodz Cen- } \\
\text { tre, (Railway Station) Factory, City Gate, exit to Piotrkowska } \\
\text { Street” (M_IK27a). }\end{array}$ \\
\hline $\begin{array}{l}\text { - stadiums, sports and } \\
\text { recreation centres } \\
\text { - tourist and business } \\
\text { services facilities }\end{array}$ & $\begin{array}{c}\text { “...to adopt (...) sports (...) development strategies here (...) } \\
\text { the potential is (...) that we have a very well-developed sports } \\
\text { infrastructure (...) (two football stadiums), a large hall (...) } \\
\text { with a capacity of (...) almost } 15 \text { thousand. (..) and a small } \\
\text { hall, which (...) has two training centres for football players } \\
\text { and for rugby players (...) we have still cheap land (...) the } \\
\text { office space will be expanded (...) we have a very well-de- } \\
\text { veloped hotel base and new hotels are also being built (...)" } \\
\text { (M_IK27a). }\end{array}$ \\
\hline $\begin{array}{l}\text { - factories and post-in- } \\
\text { dustrial places } \\
\text { - construction of the } \\
\text { place (architecture) }\end{array}$ & $\begin{array}{l}\text { "...we think that what we can show about Lodz this (...) } \\
\text { post-industrial spaces (...). “...the Art Factory or the Muse- } \\
\text { um of Textile show in promotional materials post-industrial } \\
\text { Lodz, modern Lodz, cultural Lodz (...) be it the Manufactory } \\
\text { or (...) the off-Piotrkowska (...) the truth is, there are things } \\
\text { that complement each other" (M_IK14). } \\
\text { City of Lodz “...it is unique in terms of architecture (...). We } \\
\text { are (City of Lodz is) a palace town (...) we have such beautiful } \\
\text { palaces and preserved in such good condition (...) the Pastor's } \\
\text { Mill makes an impression (...), no matter which way you } \\
\text { look at it Manufaktura is such a post-industrial tissue (...)" } \\
\text { (TM_IK11). }\end{array}$ \\
\hline
\end{tabular}

Source: own study based on research.

their state of preservation (e.g. Poznański Palace, Biedermann Palace). Table (1a) contains selected statements regarding these proposals.

To a lesser extent, comments about the subcategory "cultural institutions" were observed. "Cultural institutions (...) are cinemas, theatres, or the Lodz Events Centre (...), which also creates its events in primarily urban spaces" (M_IK27a). "We have a lot to show (...) the (Lodz) National Centre of Film Culture is being created here" (TM_IK15). There were also comments on the EC1 Science and Technology Centre, the Lodz Tourist Organisation, the Museum of Cinematography, the Art Factory together with the Art Incubator, the Central Museum of Textiles, and the Museum of Art. 
On the subject of "universities and schools" it was said: "we have a good academic centre, a good potential workforce to meet employers' needs" (TM_IK15a). There were comments about technical universities (Technical University of Lodz) and artistic universities (e.g. Leon Schiller State Higher School of Film, Television, and Theatre).

In the area of the subcategory "works of art and exhibitions", comments were made about their "post-industrial character" (M_IK14A) that Lodz "looks good in the world of literature" (TM_IK25), but sculpture, painting, or drawing were not forgotten either.

On the other hand, when analysing the statements from the area of "intangible cultural resources" influencing the brand building of the city of Lodz, the dominant role was taken over by the subcategory of the "cultural offer of the Cultural Institutions (CI)". Within it, the most frequent reference was made to events that were most often organised in urban (town) space. Festivals and concerts, which are hugely attractive for audiences, were often mentioned here.

The respondents commenting on the festivals referred to "(...) events which (...) have already entered the Lodz tradition and have been here for a very long time, e.g. the Festival of 4 Cultures" (M_IK26); “...of course we have the Design Festival and it's fascinating” (TM_IK24); “...we have the Transatlantic" (TM_IK11), or the International Festival of Comics and Computer Games, the International Festival of Photography, which also brought together a great many artists" (TM_IK15a), “(...) the Festival of Light is probably recognisable" (T_IK13a). The Festival - Colours of Poland, Soundedit, Fashion Week, International Animation Art Festival AnimArt were also mentioned. Concerts included Justin Bieber, Black Sabbath, Iron Maiden, Shakira, Rihanna, Sting, and others.

It is worth mentioning that building a city's brand should start with defining the city's identity. The respondents also expressed their opinions on this subject, talking about Lodz on the cultural market as a historically young city of various cultures and architectural styles (avant-garde, secession, industrialism), post-industrial, cinematic, open, modern, textile, design, experimental, a city with an excellent organisational base of cultural events, ageing, and creative. For example, quoting: “(...) Lodz's identity, which I mean by this, is a reference to the avant-garde in some sense all the time to the cinematic Lodz, of course, it looks so different, but also the reference to the industrial heritage. (...) All that constitutes (...) the strength of Lodz is also (...) the initiatives of individual artists, creators, some groups that are not 
formal groups, but above all create (...) such a non-urban nature. It is an open climate that allows for the realisation of crazy ideas that would not necessarily happen in other cities. That this is a young city (...), no such historical baggage is a burden in some sense (...). Lodz is not a conservative city (...) Lodz is progressive (...), as evidenced by the whole situation relating to the broadly understood avant-garde and all those streams, artistic activities which are now also functioning and which are not fully reflected in other cities" (M_IK14A).

In the process of building the city's brand, its "environment" is essential; i.e. for whom the brand is made. Based on the research, artistic and creative groups, residents and tourists, students, investors, Internet users or famous people who were born or succeeded in a given area (e.g. Władysław Strzemiński), as well as professionals in their work, were selected.

During the analysis of "intangible cultural resources", one more subcategory of "organisation" was distinguished within which a division into codes (statements of respondents) characterised by a "positive" image of city branding, as well as "negative", which should be understood as lost benefits for the city (neglected areas of culture and problems relating to the financing of culture). This subcategory allowed to see the course of current and future activities in Lodz, which could have a significant impact on building the city's brand strength. Positive perception within the organisational activities is given to: well-organised events, background of specialists in various professions, skilful cultural offer planning, attracting different audiences (students, famous people, tourists, proud inhabitants, investors, etc.), ability to see opportunities and threats for the cultural development, e.g. to use communities to promote the city, cooperation with various other cultural entities, implementation of various artistic projects, reconstruction of the film industry, ability to earn money from creative industry, but also self-financing.

However, within the scope of organisational activities, the following issues are negatively perceived: the way of financing cultural institutions, getting rid of flagship events such as the CameraImage International Film Festival, negligence of the historical areas of Lodz's activity, e.g. film production, textile industry's history, poorly made decisions relating to the investments in the city or the demolition of old buildings with significant architectural value for Lodz, etc.

It should be noted that most of the designated codes, which describe the value of the "organisation" subcategory show a relation (in Table 1: 
Z1, Z2 and Z3, and Table 2: Z4) with the skills and capabilities of people from the cultural environment of Lodz, thanks to whom it was possible to assess their activities. Therefore, the following part of the article refers to the professional profile of cultural managers, who are representatives of the community building the strength of the city of Lodz's brand. For further analytical purposes, the authoress of the article made an assumption $(\mathrm{Z})$ that among the questioned managers, the perception of positive and negative activities in the area of creating the city' brand in the cultural market may be conditioned by the managers' own professional experience.

\section{The profile of the manager of the cultural institution in the city of Lodz's branding process}

Prompted by the above assumption (Z), the authoress of the article developed a profile of a person who manages a cultural institution in Lodz. The research aimed at finding out whether the manager of a cultural institution is aware of the impact of their own decisions on building the city's brand, as well as whether they are predisposed to be an ambassador/creator of the city's brand. The category tree presented below, which is the result of an analysis based on the grounded theory methodology, allowed to define the silhouette of the cultural institution manager and to formulate initial assumptions or descriptions (Table 2).

The codes shown represent the values of the obtained categories. The R1-3 and Ra-d symbols are selected as examples of the relations the author wanted to define between the codes or categories, bearing in mind the objective adopted in the article. The proposed relationships are only a part of the possibilities of the category tree in Table 2 with the categories in Table 1.

Based on the category tree describing the profile of the manager of cultural institutions (Table 2), it can be observed that two main categories were distinguished: "human maturity" and "professional experience". The second category is not surprising when it comes to the employee profile. The subcategories defined within it are the central areas that are usually described in each employee's CV (Curriculum vitae). However, the authoress of the article underlined a particular importance of the subcategory "experience in the industry/sector (Ra)". It might be an important criterion that will have a huge impact on the perception of the world but will also influence the manager's 


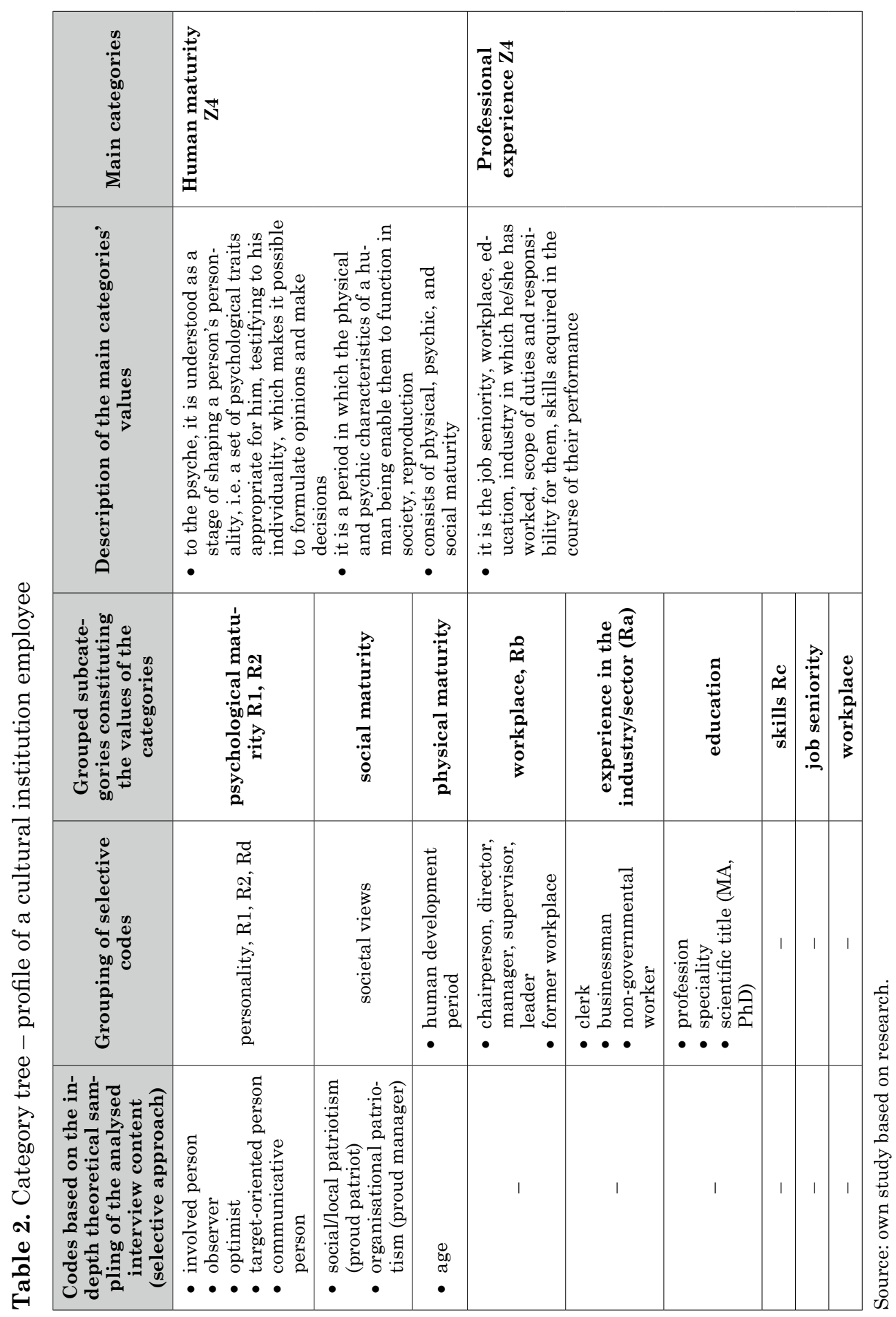


performance in the environment in which he or she works. Within this category, it is also possible to find dependencies/relationships between the subcategories "workplace (Rb)" and "skills (Rc)". On the other hand, the subcategory "industry/sector experience (Ra)" may be significantly related to the subcategory "psychological maturity personality (Rd)" from the category "human maturity". One of the main categories which deserves attention is "human maturity", which is not a starting point for an interview in everyday life of recruiting employees. Usually, it is the CV that provides the basis for an invitation to further cooperation, while the psychological area can be taken into account at a later recruitment stage. The analysis shows that this criterion (frequency of statements and scope of codes giving value to subcategories) dominates over the "professional experience (Z4)", but the importance of the latter cannot be rejected in preliminary research searching for dependency/impact. The "personal" characteristics within this category can be more relevant and necessary at work than those derived from the "professional experience" (Table 2, Z4). The authoress also attempted to refer to the categories defined in the research on the cultural resources' potential in the context of the branding of Lodz presented in Table 1 (Table 1, Z1-3). It should be noted that the proposed dependencies/relationships are not the only ones; their choice was dictated by the sense of the content of the respondents' statements and the purpose of the article.

While analysing the respondents' comments on the observed relationships in Tables 1 and 2, the authoress of the article put forward the following assumptions, which require experimental verification in the future:

- R1-Z: Psychological maturity (personality) of a culture manager translates to rational perception/use of cultural resources to build a brand of the city of Lodz.

- R2-Rc: Personality of a cultural manager correlates with a rational perception/use of cultural resources to create the city of Lodz's brand if a manager has a diverse (rich) range of skills acquired during his or her professional experience.

- R2-Rb: The skills of a culture manager are conditioned by his or her workplace.

- R2-Rc: If a manager has a great range of professional skills, he or she can effectively use cultural resources potential to develop the city of Lodz's brand. 
- Ra-Rd: The manager's experience in the business/official/non-governmental sector translates to his/her observation skills, which allow to see the benefits and ineffective use of cultural resources.

\section{CONCLUSION}

The conducted research shows that Lodz has a sufficient range of cultural resources, which have an impact on building the city's brand and position on the Polish or international arena. The dominant cultural resources are those that are part of the urban space, but also those that are created by cultural institutions in the form of a proposed cultural offer. It is essential that Lodz does not lose its flagship events because based on research it was observed that they are the ones that contribute the most to attracting people to the city and its brand. Identity is important in the process of building a city's brand. Undoubtedly, the city of Lodz has it. The statements by the managers showed pride with what Lodz represents, its post-industrial character, new openness, and creativity in action. At the same time, it indicated which areas were abandoned for various reasons, e.g. weakened film industry, negligence of the city' textile history, or the fact that cultural institutions are underfinanced and relations with local governments need to be improved. The surveyed culture managers were able to see the potential of the city's resources, although this does not mean that they had used these resources in the process of building the city's brand. Their professional maturity allows them to notice opportunities for the development of the city's brand and helps in making decisions. However, this subject requires deeper research. Based on the methodology of the theory established in the article, some assumptions in this area were presented, but they are only a starting point for further research on the influence of the cultural institution manager on building the city's brand.

\section{REFERENCES}

Baker, B. (2012). Destination Branding for Small Cities, Second Edition, The Essentials for Successful Place Branding. Portland: Creative Leap Books, 28.

Bellon, M. (2019). Szefowa IBM uważa, że zatrudnianie ludzi na podstawie dyplomu, jest błędem. Business Sinder Polska, https://businessinsider.com.pl/ 
rozwoj-osobisty/kariera/kariera-w-branzy-technologicznej-rady-szefowej-ibm/ esre9wc (access: 10 ${ }^{\text {th }}$ February 2019).

Ciekanowski, Z. (2015). Rola menedżera w organizacji. Zeszyty Naukowe Uniwersytetu Przyrodniczo-Humanistycznego w Siedlcach. Administracja i Zarzadzanie, 34, 107, 185-195.

Ciesielska, M. (2007). Lider poszukiwany. Jak stworzyć model kompetencji pożądanego lidera zespołu. Personel, 7.

Fakeye, P. C. \& Crompton, J. L. (1991). Image differences between prospective, first time and repeat visitors to the Lower Rio Grande Valley. Journal of Travel Research, 30, 10-16.

Gibbs, G. (2011), Analiza danych jakościowych. Warszawa: Wydawnictwo Naukowe PWN. Informacja o zawodzie - menedżer kultury (2010), 4.

Kangas, J. (1998). Helsingin imago Lontoossa. Helsingin kaupunginkanslian tiedotustoimisto. Helsinki, 1-8.

Konecki, K. (2000). Studia z metodologii badań jakościowych. Teoria ugruntowana. Warszawa: Wydawnictwo Naukowe PWN.

Korczyńska, M. (2006). Marka miasta. Marketing i Rynek, 12, 2-10.

Kotler, Ph. \& Lee, N. (2008). Marketing w sektorze publicznym. Mapa drogowa wyższej efektowności. Warszawa: Wydawnictwa Akademickie i Profesjonalne, Wyższa Szkoła Przedsiębiorczości i Zarządzania im. L. Koźmińskiego.

Łuczak, A. (2000). Istota tożsamości miasta. Samorzqd Terytorialny, 10, 46-53.

Markowski, T. (2002). Marketing terytorialny. Studia KPZK PAN, 62.

Niedbalski, J. (2014). Komputerowe wspomaganie analizy danych jakościowych. Zastosowanie oprogramowania NVIVO $i$ Atlas.TI w projektach badawczych opartych na metodologii teorii ugruntowanej. Łódź: Wydawnictwo Uniwersytetu Łódzkiego.

Polityka Rozwoju Kultury 2020+ dla Miasta Łodzi. Łódź.

Seaton, A. V. \& Bennett, M. M. (1996). Marketing Tourism Products. Concepts, Issues, Cases. London: Thompson Business Press, 540.

Seweryn, R. (2013). Kryzys gospodarczy a ewolucja marki Kraków w opinii hiszpańskich turystów. Współczesne Zarzqdzanie, 1, 51-61.

Simerson, K. B. \& Venn, M. L. (2010). Menedżer jako lider. Warszawa: Oficyna a Wolters Kluwer Business.

Szromnik, A. (2007). Marketing terytorialny. Miasto i region na rynku. Kraków: Oficyna a Wolters Kluwer Business.

Szwajca, D. (2009). Jak zmienić wizerunek miasta. Marketing i Rynek, 2.

Strategia Zarzadzania Marka Eódź na lata 2010-2016, Łódź. 
Tomaszuk, A. (2013). Sylwetka menedżera w świetle teorii zarządzania i badań własnych na przykładzie menedżerów sektora budownictwa województwa podlaskiego. Economics and Management, 4, 67-81.

Wierżyński, W. (2018). Menedżerowie nowej ery, http://www.pi.gov.pl/PARP/chapter_86196.asp?soid=4A743DA96D4F422C94CAB3F7CACF3036 (access: $15^{\text {th }}$ November 2018).

Williams, M. (2009). Mistrzowskie przywództwo. Kraków: Oficyna Wolters Kluwer Business.

\section{BUDOWANIE MARKI ŁODZI NA PODSTAWIE ZASOBÓW KULTURY - WYNIKI BADAŃ JAKOŚCIOWYCH}

\section{Abstrakt}

Tło badań. Marka miasta jest konstruktem szczególnie złożonym i wielowymiarowym. Kluczowym jej komponentem jest tożsamość, która przyczynia się do budowania wizerunku miasta. Coraz częściej podstawę wizerunku stanowią zasoby z sektora kultury czy przemysłu kreatywnego. Należy tutaj wspomnieć, że istotną rolę w procesie budowania wizerunku miasta przypisuje się osobom twórczym z umiejętnościami dostrzegania szans i zagrożeń w przyszłości oraz elastycznego dostosowywania się do zmian w otoczeniu.

Cel badań. Artykuł przedstawia potencjał zasobów kultury miasta Łodzi w procesie budowania marki miasta. Pokazuje również stopień ich wykorzystania lub też zaniechania, spowodowanego być może niewystarczajacym doświadczeniem zawodowym menedżerów kultury. W artykule opisano także profil menedżera instytucji kultury.

Metodologia. Podstawę empiryczną stanowią wywiady prowadzone z menedżerami i pracownikami zatrudnionymi w miejskich instytucjach kultury w Łodzi. Analiza danych została przeprowadzona zgodnie z zasadami metodologii teorii ugruntowanej.

Kluczowe wnioski. Łódź posiada wystarczający wachlarz zasobów kultury, które mają wpływ na budowanie marki miasta. Dominującymi zasobami są te składające się na przestrzeń miejską oraz te, które są tworem instytucji kultury w postaci proponowanej oferty kulturalnej. Łódź nie powinna tracić swoich flagowych wydarzeń, gdyż one mają największy czynnik przyciagania ludzi do miasta i jej marki. Łódź reprezentuje sobą postindustrialny charakter, nowoczesną otwartość czy kreatywność w działaniu. Ma również obszary zaniedbane, np. osłabiony przemysł filmowy, zaniedbaną historię włókiennictwa czy też niedofinansowane instytucje kultury, ograniczone relacje z władzami samorządowymi. Badani menedżerowie dostrzegaja potencjał posiadanych zasobów przez miasto, choć to nie znaczy, że potrafia je efektywnie wykorzystać w procesie budowania marki miasta. Ich dojrzałość zawodowa pozwala zapewne na dostrzeganie szans i zagrożeń otoczenia oraz pomaga w podejmowaniu decyzji. Jednakże ten temat wymaga głębszych badań.

Słowa kluczowe: marka miasta, zasoby kultury, teoria ugruntowana, instytucje kultury 